\title{
Abuse of Rights in English Contract Law: Hidden in Plain Sight?
}

\author{
Solène Rowan*
}

\begin{abstract}
The article argues that the fetters on the exercise of unilateral contractual discretionary powers that were defined in Braganza $\vee$ BP Shipping Ltd and the limits on damages clauses as redefined in Cavendish Square Holding BV v Talal El Makdessi are imposed to prevent the abuse of contractual rights or freedoms and this is suggestive that a broader principle against the abuse of rights might be at work in English contract law. Whilst English law has traditionally been understood as rejecting a free-standing and general doctrine of abuse of rights, the article explains why this should not be regarded as an obstacle to the proposed analysis. In both the context of contractual discretion and damages clauses, the central importance of abuse is evident from the tests that are applied, the factors that the authorities tell us are relevant to their application and both the high bar for the court to intervene and the flexibility of the relevant standards, which filter out only the most egregious and inadmissible cases.
\end{abstract}

Key words: abuse of rights; contractual discretion; penalty clause; good faith; French law.

\section{INTRODUCTION}

That contracting parties are, absent incapacity or illegality, entitled to create mutual rights and duties by agreement, is well established and uncontentious in English law. ${ }^{1}$ The general principle is that 'parties are free to contract as they may see fit'. $^{2}$ Aside from in relation to contracts involving consumers, whose perceived vulnerability is protected through regulation, ${ }^{3}$ the courts are reluctant to disturb how the parties have chosen to balance their competing interests and allocate risk. There is no general jurisdiction to invalidate or vary freely negotiated contractual rights by resort to concepts of fairness, reasonableness and good faith.

The same is true of the manner in which those rights are exercised. As Lord Reid said in White and Carter (Councils) Ltd $v$ McGregor, ${ }^{4}$ 'it never has been the law that a person is only entitled to enforce his contractual rights in a reasonable way and that a court will not support an attempt to enforce them in an unreasonable way'. ${ }^{5}$ Nor do the courts usually scrutinise the motives of a party exercising such a right. He can do so 'for a good reason or a bad reason or no reason at all'. ${ }^{6}$ The precedence given to the contract terms, which are usually enforced dispassionately and without

\footnotetext{
* Associate Professor and Futures Scheme Award holder, the Australian National University. My thanks are owed to Gregg Rowan, Peter Turner and the editorial committee and the anonymous referees of the Modern Law Review for their comments on earlier drafts of this article.

${ }^{1}$ Photo Production Ltd v Securicor Transport Ltd [1980] AC 827 (HL).

2 Suisse Atlantique Société d'Armement SA v NV Rotterdamsche Kolen Centrale [1967] 1 AC 361 (HL) at 399 (Lord Reid).

${ }^{3}$ Consumer Rights Act 2015.

${ }^{4}$ [1962] AC 413 (HL Sc).

${ }^{5}$ ibid at 1183 (Lord Reid).

${ }^{6}$ Chapman v Honig [1936] 2 QB 502 at 520 (CA) (Pearson LJ).
} 
judicial meddling, is a source of satisfaction amongst English contract lawyers and is vaunted as promoting commercial certainty. ${ }^{7}$

Yet there are also contexts in which the courts have imposed outer limits on contractual rights and freedoms in order to prevent their misuse. Two such contexts, both of which have been subject to recent developments, are contractual discretion and damages clauses. In Braganza v BP Shipping $L t d,{ }^{8}$ the Supreme Court defined the review jurisdiction of the court over the exercise of unilateral contractual discretionary powers. This is implemented through an implied term and rests on concepts of honesty, good faith, propriety of purpose, reasonableness, rationality, arbitrariness, capriciousness and perversity. As regards damages clauses, the Supreme Court in Cavendish Square Holding BV v Talal El Makdessi ${ }^{9}$ recently redefined the test for ascertaining whether a clause is penal, bringing an end to the binary search for a genuine pre-estimate of loss in favour of a more nuanced and evaluative enquiry. There is now greater flexibility to assess the enforceability of damages clauses by reference to notions of legitimate interest, unconscionability, exorbitance and extravagance. A damages clause will be unenforceable where it does not serve a legitimate interest in performance and is extravagant, exorbitant or unconscionable in amount.

The thesis of this article is that these limits on contractual discretionary powers and damages clauses are imposed to prevent the abuse of contractual rights or freedoms and this is suggestive that a broader principle preventing rights from being abused might be at work in English contract law. In these specific areas, the relevance of abuse is increasingly discernible following recent developments. The central importance of abuse is evident from the tests that are applied and the factors that the authorities tell us are relevant to their application. It is also apparent in the low standard that is set, which filters out only the most egregious and inadmissible cases. The right holder needs only to have acted with some proper basis or in a way that is justifiable and the court will decline to intervene.

'Right' is used here in a broad sense that encompasses contractual advantages, ${ }^{10}$ such as entitlements, powers and freedoms agreed by the parties or conferred by the general default rules of contract law, and which can be given effect in court. 'Abuse' refers to misuse, that is, the improper and objectionable use of the right. ${ }^{11}$ The principle that prevents abuse sets limits on how the right is exercised, ${ }^{12}$ requiring the right-holder to refrain from using it in certain, inadmissible, ways despite

\footnotetext{
${ }^{7}$ See for example Golden Strait Corp v Nippon Yusen Kubishika Kaisha (The Golden Victory) [2007] 2 AC 353 (HL) at [1] (Lord Bingham). On the contentment of English lawyers with their contract law, see P MacMahon, 'The Englishness of English Contract Law' (paper on file with author, presentation at the LSE Law Department on 28 February 2020).

8 [2015] UKSC 17 (SC).

${ }^{9}$ With its conjoined appeal ParkingEye Ltd v Beavis [2016] AC 172 (SC).

${ }^{10}$ On the notorious difficulty of defining 'right', see W.N. Hohfeld, 'Fundamental Legal Conceptions as Applied in Judicial Reasoning' (1916-17) 26 Yale LJ 710 for whom '[t]he word 'right' is used generically and indiscriminately to denote any sort of legal advantage, whether claim, privilege, power or immunity'.

${ }^{11}$ H.C. Gutteridge, 'Abuse of Rights' (1933) 5 CLJ 22; J Gordley, 'The Abuse of Rights in the Civil Law Tradition' in R. De La Feria and S. Vogenauer (eds), The Prohibition of Abuse of Law: An Emerging Principle of EU Law? (Oxford: Hart, 2011) 33; K. Zweigert and U. Drobnig, International Encyclopaedia of Comparative Law (Brill, Nijhoff, online edition), Volume XI: Torts, Chapter 2 (1980).

12 'Abuse of rights' has mostly been analysed in civilian jurisdictions, where principles of abuse in varying forms and with different scope and contours have been adopted and developed. See Gutteridge, n 11 above; P. Catala and J.A. Weir, 'Delict and Torts: a Study in Parallel - Part II' (1963-1964) 38 Tul L Rev 221; E. Reid, 'Abuse of Rights in Scots Law' (1998) 2 Edinburgh L Rev 129; Gordley $n 11$ above; S. Whittaker, 'Comments on 'Abuse of Law' in European Private Law' in R. De La Feria and S. Vogenauer (eds), The Prohibition of Abuse of Law: An Emerging Principle of EU Law? (Oxford: Hart, 2011) 253 who says at 258 that 'the doctrine of abused of rights is used to control the exercise of ascertained and delineated rights...' and is a mechanism that qualifies the exercise of the right; International Encyclopedia of Comparative Law (n 11); G.M. Redmann, 'Abuse of Rights: an Overview of the Historical Evolution and the Current Application in Louisiana Contracts' (1987) 32 Loy L Rev 946; S. Saintier, 'The elusive notion of good faith in the performance of a contract, why still a bête noire for the civil and the common law?' [2017] JBL 441; J.H. Crabb, 'The French Concept of Abuse of Rights' (1964) 6 Inter-Am L Rev 1; J.E. Scholtens, 'Abuse of Rights' (1958) 75 S African LJ 39; A. Angus, 'Abuse of Rights in Contractual Matters in
} 
seemingly being entitled to do so. At its core is the idea that certain rights, even though broad and largely unfettered, nonetheless cannot be misused.

Whilst English law has traditionally been understood as rejecting a free-standing and general doctrine of abuse of rights, this should not be regarded as an obstacle to the proposed analysis. On close inspection, the cases usually cited against the doctrine actually stand for the narrower proposition that malicious or improper motives are irrelevant and cannot be relied upon to impugn the exercise of a right. ${ }^{13} \mathrm{~A}$ lawful act cannot by malicious motives become unlawful. However, they are concerned only with malicious abuse, not other possible forms of abuse. It will be argued that Braganza and Makdessi show that there are other situations where the court will intervene to restrain the misuse of rights. Depending on the context, the right-holder can be required to refrain from acting dishonestly, outside the limits of the right, inconsistently with the purpose for which it was conferred or without a legitimate interest or any proper basis. These limitations collectively operate to prevent abuse. Yet this is camouflaged by concepts and mechanisms that are more familiar to English law.

It should not be thought that this article argues for the importation into English contract law of new rules against the abuse of rights. Instead, its purpose is to show is that there are such rules already operating in two particular contexts: contractual discretionary powers and damages clauses. Nor should it be understood as arguing that these rules, even if they are suggestive of a broader principle, justify the recognition of some general overarching doctrine of abuse of rights. It contends only that, in these two contexts, it is the prevention of abuse that limits how the right can be exercised and defines the boundary between what is acceptable, which accounts for the large majority of cases, and what is not, which can be seen in relatively rare cases around the margins. This will be shown to have parallels with France, where it is openly accepted that the vice addressed by the equivalent rules on contractual discretionary powers and penalties is abuse, and abuse of rights is a recognised principle.

Acknowledging abuse as the touchstone of whether or not the right has been validly exercised in these contexts assists in understanding the cases and identifying how and where the line for impermissible conduct is drawn. It might also prompt other questions, such as whether a broader principle against the abuse of rights is covertly operating in other contexts and, if so, further work on the content and scope of the principle. It is beyond the purpose of this article to explore these questions, but they are touched upon and suggested as topics for further consideration by way of concluding remarks.

\section{THE REJECTION OF ABUSE OF RIGHTS AS A GENERAL DOCTRINE}

The language of 'abuse' is not generally part of the lexicon of English private lawyers. ${ }^{14}$ There is no recognised doctrine of abuse of rights in England and the notion has traditionally aroused suspicion. ${ }^{15}$

the Province of Quebec' (1962) 8 McGill LJ 150; J. Perillo, 'Abuse of Rights: a Pervasive Legal Concept' (1995) 27 Pac LJ 37; A.N. Yiannopoulos, 'Civil Liability for Abuse of Right: Something Old, Something New' (1993) 54 La L Rev 1173; ; J. Voyame, B. Cottier and B. Rocha, 'Abuse of Rights in Comparative Law' in Council of Europe, Abuse of Rights and Equivalent Concepts: The Principle and Its Present Day Application (Strasbourg, Council of Europe 1990) 23; M. Byers, 'Abuse of Rights: an Old Principle, a New Age' (2002) 47 McGill LJ 389; F. Losurdo, 'Beyond Certainty: Abuse of Rights and Balancing in Contemporary Jurisprudence' (2015) 6 Comp L Rev 1; F. Ranieri, 'Bonne Foi et Exercice du Droit Dans la Tradition du Droit Civil' (1998) RIDC 1055; B. Pardy, 'Disabusing the Common Law of 'Abuse of Rights' the Only Legitimate Rule Redux'(2018) 84 SCLR 201; D.J. Devine, 'Some Comparative Aspects of the Doctrine of Abuse of Rights' (1964) 1964 Acta Juridica 148.

${ }^{13}$ Bradford Corp v Pickles [1895] AC 587; Allen v Flood [1898] AC 1.

${ }^{14}$ Abuse of process is however a well known doctrine in procedural law.

${ }^{15}$ Gutteridge, n 11 above. 
The authorities routinely cited ${ }^{16}$ as rejecting the doctrine are the tort cases of Bradford Corp v Pickles ${ }^{17}$ and Allen v Flood. ${ }^{18}$ However, on a fair reading, neither goes nearly this far. Instead, they establish only that the exercise of a right is not invalidated by improper motives.

In Bradford Corp v Pickles, a landowner intentionally abstracted water percolating under his soil so as to prevent it from reaching the land of his neighbour. It was held by the House of Lords that he had a right to do so, regardless of his motives. Whether the right was exercised bona fide to improve his own land, maliciously to injure his neighbour, or to induce the neighbour to buy him out, this would be permissible. As Lord Halsbury L.C. said, 'if it was a lawful act, however ill the motive might be, he had a right to do it. If it was an unlawful act, however good his motive might be, he would have no right to do it'. ${ }^{19}$ This was confirmed in Allen v Flood, another House of Lords case. Lord Watson stated that 'the existence of a bad motive, in the case of an act which is not itself illegal, will not convert that act into a civil wrong for which reparation is due'. ${ }^{20}$

Bradford Corp v Pickles and Allen v Flood are widely understood as rejecting a principle of abuse of rights in English law. As Catala and Weir noted, Bradford Corp 'is regarded as definitely negativing a doctrine of abuse of rights for the common law'. ${ }^{21}$ Gutteridge, referring to both Bradford Corp and Allen, stated that 'the theory of the abuse of rights is one which has been rejected by our law ... our law has not hesitated to place the seal of it approval upon a theory of the extent of individual rights which can only be described as the consecration of the spirit of unrestricted egoism'. ${ }^{22}$

Whilst Bradford Corp and Allen v Flood are tort cases, the principle for which they stand also applies in contract law, which is the focus of this paper. When presented with evidence of bad motives for the exercise of a right, the court will hold its nose. In Chapman v Honig, ${ }^{23}$ a landlord gave notice to quit to his tenant because the tenant had testified against him in court. Pearson $\amalg$ said that 'the inquiry is limited to ascertaining whether the act has been done in accordance with the provisions of the contract. I cannot think of any case in which such an act might be invalidated by proof that it was prompted by some vindictive or other wrong motive. Motive is disregarded as irrelevant ${ }^{\prime 24}$ Contract law largely operates without regard to blame, 'not to punish wrongdoing but to satisfy the expectations of the party entitled to performance'. ${ }^{25}$

Several reasons have been advanced for disregarding the motives for the exercise of a right. One is potential evidential difficulties. Malicious or improper intention would have to be proven, which involves a form of psychological enquiry. ${ }^{26}$ The complexity of ascertaining the state of a mind is perceived to be too difficult and burdensome. ${ }^{27}$ Another is that the court would be required to make a moral judgement, which is thought to be more appropriate to criminal law than tort and contract. ${ }^{28}$

\footnotetext{
${ }^{16}$ eg Gutteridge n 11 above; Catala and Weir, n 12 above, 247; Reid, n 12 above, 141-146; Devine, n 12 above, 164-179; International Encyclopaedia of Comparative Law, n 11 above at [233] R. Hooley, 'Controlling Contractual Discretion' [2013] CLJ 65, 84.

17 [1895] AC 587 (HL). It has been shown that the seemingly hard-and-fast rule in Bradford Corp and Allen is actually more nuanced than commonly thought and motives can be relevant in some contexts: J. Murphy, 'Malice as an Ingredient of Tort Liability' [2019] CLJ 355; Catala and Weir, n 12 above.

18 [1898] AC $1(\mathrm{HL})$.

19 [1895] AC $587(\mathrm{HL})$ at 594.

20 [1898] AC $1(\mathrm{HL})$ at 92.

${ }^{21}$ Catala and Weir, n 12 above, 247.

22 Gutteridge, $\mathrm{n} 11$ above, 22.

23 [1963] 2 ER 513 (CA).

24 [1963] 2 ER 513 (CA) at 522-3. See also White and Carter (Councils) Ltd v McGregor [1962] A. 413 (HL SC) at 1183 (Lord Reid).

${ }^{25}$ Co-operative Insurance Society v Argyll Stores (Holdings) Ltd [1998] AC 1 (HL) at 15 (Lord Hoffmann). See also Ruxley Electronics and Construction Ltd v Forsyth [1996] AC 344 (HL) 353 (Lord Bridge) and 365 (Lord Lloyd).

${ }^{26}$ F.H Lawson, 'Notes on the History of Tort in the Civil Law' (1940) 22 JCL 136 at 162; Murphy, n 17 above, 372; Devine, $\mathrm{n} 12$ above, 149.

${ }^{27}$ Murphy, $\mathrm{n} 17$ above, 371-3 disagreeing with this argument.

${ }^{28}$ Gutteridge, n 11 above, 43; Lawson, n 26 above, 162; Murphy, n 17 above, 372.
} 
There are also fears of uncertainty ${ }^{29}$ and to restrain the liberty of individuals who are acting within the formal limits of their rights is considered undesirable. ${ }^{30}$

Whatever is the relevance of motive to whether or not a right is exercised validly, it is submitted that this is all that Bradford Corp, Allen and Chapman are concerned with. They do not hold that the exercise of a right is unimpugnable on grounds other than bad motives, or in all circumstances. ${ }^{31}$ As such, they say nothing as to other potentially objectionable ways in which contractual rights might conceivably be misused. The next two sections of this paper seek to show that there are situations where the courts do in fact intervene to restrain the misuse of rights. This is done not by reference to the motives of the right-holder, but instead where the right is diverted from its original purpose or exercised dishonestly, without proper basis or without advancing any legitimate interest.

Such interventions have occurred without any recognition of a principle or rule(s) against the abuse of rights. Instead they have been rather fragmented, relying on mechanisms that are more familiar to English law. These include the implication of terms in fact and reference to public policy. This should not however disguise what in substance is the prevention of abuse of rights or the discernible parallels in the rationales and the requirements that must be satisfied for the court to intervene. To recognise the role of abuse would be to bring greater understanding in both respects.

\section{ABUSE IN THE EXERCISE OF CONTRACTUAL DISCRETIONARY POWERS}

The prevention of abuse in the exercise of contractual discretionary powers ${ }^{32}$ is discernible in a number of ways. These include the language of the court when deciding whether or not the exercise of a contractual discretion should be impugned and the rationale for and scope of the review undertaken by the court. There have been attempts to explain this as rooted in good faith, but it will be shown that abuse of rights is a truer organising principle for the case law.

\section{Protecting against abuse as the rationale for intervention}

Unilateral contractual discretionary powers are common in complex contracts. ${ }^{33}$ One party is conferred by the contract with a power to make a decision that affects the rights and obligations of both of the contracting parties. Over the last 30 years, the courts have shown greater willingness to scrutinise how such powers are exercised, with outer limits of acceptability increasingly imposed. This is generally effected through the implication of a term that the discretion should be exercised honestly, in good faith and not for an improper purpose, capriciously, perversely, arbitrarily or irrationally. ${ }^{34}$ It is justified as being necessary to give effect to the reasonable expectations of the parties. $^{35}$

\footnotetext{
${ }^{29}$ Lord Hoffmann in OBG Ltd v Allan [2008] 1 AC 1 at [14]; Gutteridge, n 11 above, 42.

30 Gutteridge, $\mathrm{n} 11$ above, 35 and 45.

${ }^{31}$ Devine, $\mathrm{n} 12$ above, 155.

32 The term 'power' is used throughout this section of the article in the same way as in the case law on reviewable unilateral contractual discretions. It refers to the right of one party to make a decision that affects the rights and obligations of both contracting parties. It is discretionary in that the decision-maker has a choice between several possible courses of action or outcomes. For a discussion of the meaning of discretion in the context of reviewable contractual powers see Hooley, n 16 above, 9-10; M. Bridge, 'The Exercise of Contractual Discretion' (2019) 135 LQR 227, 236-7; J. Varuhas, 'Three Issues in the Law of Contractual Discretion' (forthcoming OJLS).

${ }^{33}$ As noted by Lady Hale at [18] in Braganza v BP Shipping Ltd [2015] UKSC 17 (SC).

${ }^{34}$ Braganza at [18] (Lady Hale); Paragon Finance plc v Nash [2002] 1 WLR (CA) [32]-[36] (Dyson LJ); Socimer International Bank Ltd v Standard Bank London Ltd [2008] Bus LR 1304 (CA) [66] (Rix LJ).

${ }^{35}$ Mid Essex Hospital Services NHS Trust v Compass Group UK and Ireland [2013] EWCA Civ 200 (CA) [82] and

[92]; Braganza at [21] (Lady Hale); Paragon Finance plc at [32]-36] (Dyson LJ).
} 
Some examples of discretionary powers to come before the courts include a provision in a mortgage agreement giving the mortgagee a discretion to vary the interest rate; ${ }^{36}$ a discretion to apportion bonuses; ${ }^{37}$ the right of a bank to call for and charge borrowers the cost of a professional valuation of their premises secured in the bank's favour; ${ }^{38}$ and the right of a shipowner to refuse to proceed to a particular port that was considered unsafe. ${ }^{39}$

The intervention of the court in these cases has been rationalised in various different ways ${ }^{40}$ but it is submitted that the common purpose is protecting against abuse. Nowhere is this more evident than in the main cases. As Leggatt $\square$ held in Abu Dhabi National Tanker Co v Product Star Shipping Ltd (No 2), ${ }^{41}$ 'the essential question always is whether the relevant power has been abused. Where $A$ and $B$ contract with each other to confer a discretion on $A$, that does not render B subject to $A$ 's uninhibited whim'. ${ }^{42}$ That the 'concern is that the discretion should not be abused' ${ }^{43}$ was affirmed by the Court of Appeal in Socimer International Bank Ltd $v$ Standard Bank London $L t d^{44}$ and also recently by the Supreme Court in Braganza v BP Shipping Ltd. ${ }^{45}$ In the latter case, Lady Hale explained that 'the courts have ... sought to ensure that ... contractual powers are not abused', ${ }^{46}$ with the risk of abuse arising from the power given to one party to affect the rights of the other party and resolve unilaterally potential conflicts of interests that typically exist in contracts. ${ }^{47}$ This risk is heightened, she said, where there is an imbalance of power between the parties, as can be the case for instance with employment contracts. ${ }^{48}$

To restrict the decision-making freedom of right-holder is perceived to be desirable for two main reasons. First, they may be tempted to exploit the power and any vulnerability of the other party to their own advantage. As Rix $L$ recognised in Socimer, 'the danger to be guarded against ... is abuse caused by self-interest'. ${ }^{49}$ Second, it is unlikely to have been intended by the parties that the rightholder should have unlimited and potentially oppressive self-interest. Rare will be the case where the other party has consented to be at the complete mercy of the decision-maker. ${ }^{50}$ In the words of Potter $\checkmark$ in Horkulak v Cantor Fitzgerald, ${ }^{51}$ 'it is presumed to be the reasonable expectation and therefore the common intention of the parties that there should be a genuine and rational, as opposed to an empty or irrational, exercise of discretion. ${ }^{52}$ To hold otherwise would be nonsensical. A 'contract

\footnotetext{
${ }^{36}$ Paragon Finance plc v Nash [2002] 1 WLR 685 (CA).

${ }^{37}$ Equitable Life Assurance Society v Hyman [2002] 1 AC 408 (HL).

38 Property Alliance Group Ltd v Royal Bank of Scotland PIC [2018] EWCA Civ 355 (CA).

${ }^{39}$ Abu Dhabi National Tanker Co v Product Star Shipping Ltd (No 2) [1993] 1 Lloyd's Rep 397 (CA).

${ }^{40}$ See for example Hooley, n 16 above; G. Leggatt, 'Contractual Duties of Good Faith' (Lecture to the Commercial Bar Association, 18 October 2016) <https://www.judiciary.uk/wp-content/uploads/2016/10/mr-justice-leggattlecture-contractual-duties-of-faith.pdf> accessed 7 September 2020.

41 [1993] 1 Lloyd's Rep 397 (CA).

42 At 404 (Leggatt LJ).

${ }^{43}$ Socimer International Bank Ltd v Standard Bank London Ltd [2008] Bus LR 1304 (CA) [66] (Rix LJ).

44 [2008] Bus LR 1304 (CA).

45 [2015] UKSC 17 (SC).

${ }^{46}$ At [18] (Lady Hale).

${ }^{47}$ At [18] (Lady Hale) and [61] (Lord Hodge); Horkulak v Cantor Fitzgerald International [2005] ICR 402 at [30] (Potter LJ).

${ }^{48}$ Braganza at [18] (Lady Hale) and [61] (Lord Hodge).

49 [2008] Bus LR 1304 at [116].

${ }^{50}$ Hooley, n 16 above, 67. Although see H. Collins, 'Discretionary Powers in Contracts' in D. Campbell, H. Collins and J. Wightman (eds), Implicit Dimensions of Contract: Discrete, Relational and Network Contracts (2003 Hart) 219, 226-231 for possible explanations as to why a party might agree to confer an unlimited discretion on the other: the risk of abuse may be voluntary and part of the consideration, perhaps agreed to in return for a reduction in the price or other compensation.

51 [2004] IRLR 942 (CA).

52 At [30].
} 
where one party truly found himself subject to the whim of the other would be a commercial and practical absurdity'. ${ }^{53}$

\section{Abuse as the determinant for the intervention of the court}

As well as explaining why the court regulates the exercise of contractual discretionary powers, the prevention of abuse is also apparent in the implied term through which this regulation is effected.

\section{The Different Types of Abuse of Contractual Discretion Covered by the Implied Term}

The implied term has variously been held to be concerned with honesty, good faith, genuineness, improper purpose, irrationality, capriciousness, perversity and arbitrariness. It is submitted that there is one common theme - abuse - underpinning these criteria, which is discernible in the cases.

Although somewhat fragmented, the criteria all speak to different forms of abuse in the exercise of discretion. For ease of analysis, they can be grouped into three main overlapping categories. ${ }^{54}$ The first coalesces around whether the exercise of discretion is bona fide. It is variously articulated as requiring that the decision be made 'honestly', 'in good faith' and 'genuinely'. The abuse is in exercising the discretion in a manner that is dishonest. This means that the state of mind of the right-holder, and potentially any impropriety in their motives, can be relevant (seemingly contrary to Bradford Corp v Pickles and Allen v Flood). To exercise a discretion in order 'to vex [the other party] maliciously' is likely to fail this standard. ${ }^{55}$ Another example can be found in Abu Dhabi National Tanker Co v Product Star Shipping Ltd (No 2). ${ }^{56}$ The shipowners invoked a contractual right in a charterparty to refuse to discharge at the port nominated by the charterers, relying on a discretion to do so where they considered the port to be dangerous. It was found that they did not genuinely believe that the port was dangerous and any such belief would in any event have been unreasonable and capricious. Their purported concerns were a pretext and the real motivation related to a collateral commercial dispute between the parties. On that basis, the discretion was not exercised validly.

The second category is the exercise of a discretion for an 'improper purpose'. This concerns the agreed limits and the spirit of the discretion. There is abuse where the right-holder makes a decision that is inconsistent with the purpose of the discretion, the limits set by the parties and the contract as a whole. ${ }^{57}$ As Lady Hale said in Braganza, the discretion 'must be exercised consistently with its contractual purpose' ${ }^{58}$ This echoes the statement of Lord Cooke in Equitable Life Assurance Society $\vee H_{y m a n}{ }^{59}$ that 'no legal discretion, however widely worded ... can be exercised for purposes contrary to those of the instrument for which it is conferred'. ${ }^{60}$ The case law shows that the courts are likely to interfere where the discretion is exercised for a purpose that is collateral ${ }^{61}$ or 'unrelated to [the right-holder's] legitimate commercial interests or ... not rationally ... thought to advance them'. ${ }^{62}$

\footnotetext{
${ }^{53}$ Nash v Paragon Finance at first instance [2002] 1 WLR 685 (Recorder Havelock-Allan QC). See also Mid Essex Hospital Services NHS Trust v Compass Group UK and Ireland [2013] EWCA Civ 200 (CA) [82] (Jackson LJ).

${ }^{54}$ Braganza at [30] (Lady Hale) and [57] (Lord Hodge).

55 Property Alliance Group Ltd v Royal Bank of Scotland Plc [2018] EWCA Civ 355; [2018] 1 WLR 3529 at [169].

${ }^{56}$ [1993] 1 Lloyd's Rep 397 (CA).

${ }^{57}$ Braganza at [30] (Lady Hale); Equitable Life Assurance Society v Hyman [2002] 1 AC 408 (HL) 459 (Lord Steyn), 461 (Lord Cooke); British Telecommunications plc v Telefonica O2 UK Ltd [2014] Bus LR 76 (SC) [37] (Lord Sumption); Gan Insurance Co Ltd v Tai Ping Insurance Co Ltd (No 2) [2001] C.L.C. 1103 (CA) [68] . See P. Sales 'Use of Powers for Proper Purposes in Private Law' (2020) 136 LQR 384 for an argument that the legal controls on the exercise of contractual discretionary powers arise from the interpretation of the relevant instrument by reference to a model of proper purposes.

${ }^{58}$ At [30].

59 [2002] 1 AC 408 (HL).

${ }^{60}$ At 460-461.

${ }^{61}$ Abu Dhabi National Tanker Co v Product Star Shipping Ltd (No 2) [1993] 1 Lloyd's Rep 397 (CA).

62 Property Alliance Group Ltd v Royal Bank of Scotland PIc [2018] EWCA Civ 355 (CA) [169].
} 
In other words, it is outside of the agreed boundaries and objectives of the discretion, which are ascertained through contractual interpretation. ${ }^{63}$

The third category is where the decision does not have a logical or factual basis ${ }^{64}$ or its outcome is outrageous. There is an assessment of how the decision is made and the rationality of the outcome, which involves asking whether the decision is 'arbitrary', 'capricious', 'perverse' or 'irrational'. ${ }^{65}$ It is similar to the Wednesbury test ${ }^{66}$ that is applied in the context of judicial review of decisions made by public bodies. ${ }^{67}$ The court investigates whether the right-holder has taken relevant considerations and no irrelevant considerations into account and also whether the decision is so outrageous that no reasonable decision-maker could have made it. ${ }^{68}$ The abuse resides in the discretion being exercised without legitimate reasons ${ }^{69}$ or in a manner that is not properly informed. It might for instance be exercised inconsistently with the normal practice of the right-holder; ${ }^{70}$ based on wrong considerations ${ }^{71}$ or otherwise inexplicably; ${ }^{72}$ or there might be no evidence as to how the decision was reached, ${ }^{73}$ even though it has a serious impact on the other party. ${ }^{74}$

\section{Varying the Level of Scrutiny According to the Risk of Abuse}

The determinative role of abuse can also be seen in how court scrutiny of the exercise of a discretion ${ }^{75}$ varies according to the type and context of the contract, ${ }^{76}$ the nature of the decision, ${ }^{77}$ the seriousness of its impact on the other party, ${ }^{78}$ and the attributes of the right-holder, in particular whether it is a substantial commercial concern. The more a party is vulnerable or the consequences are severe, the more intensive will be the review; and vice versa.

There will be less scrutiny, for instance, where the contract is commercial in nature and was negotiated at arm's length, as there is less risk of inequality of power and abuse. ${ }^{79}$ Commercial parties

\footnotetext{
${ }^{63}$ Abu Dhabi National Tanker Co v Product Star Shipping Ltd (No 2) [1993] 1 Lloyd's Rep 397 (CA) 404; Braganza [30].

${ }^{64}$ Lymington Marina v Macnamara [2007] EWCA Civ 151 (CA) [42]; Hooley, n 16 above, 77.

${ }^{65}$ Braganza [24], [29]-[30] Hale; [53] Hodge; [103] Neuberger.

${ }^{66}$ Associated Provincial Picture Houses Ltd v Wednesbury Corpn [1948] 1 KB 223 (CA).

67 Braganza at [19], [24], [29]-[30] (Lady Hale); [53] (Lord Hodge); [103] (Lord Neuberger). Resort to administrative law has generated controversy with commentators: see for example Bridge, $n 32$ above; E. Lim and C. Chan, 'Problems with Wednesbury Unreasonableness in Contract Law: Lessons from Public Law' (2019) 135 LQR 88; Varuhas (n 32).

${ }^{68}$ Braganza at [29]-[30] (Lady Hale).

${ }^{69}$ Property Alliance Group Ltd v Royal Bank of Scotland PIc [2018] EWCA Civ 355 (CA) [174]; IBM United Kingdom Holdings Ltd v Dalgleish [2017] at [57].

${ }^{70}$ Abu Dhabi National Tanker Co v Product Star Shipping Ltd (No 2) [1993] 1 Lloyd's Rep 397 (CA) at 405.

${ }^{71}$ Braganza v BP Shipping Ltd [2015] UKSC 17 (SC).

72 Mallone v BOB Industries Ltd [2002] ICR 1045 (CA) [42] and [44]; Hills v Niksun Inc [2016] EWCA Civ 115 (CA) [23]-[26].

${ }^{73}$ Watson v Watchfinder.co.uk [2017] EWHC 1275 (Comm) [94], [116]-[124]; IBM UK Holdings Ltd v Dalgleish [2018] ICR 1681 (CA) [57]-[58].

${ }^{74}$ Braganza v BP Shipping Ltd [2015] UKSC 17 (SC) [36] (Lady Hale); Mallone v BOB Industries Ltd [2002] ICR 1045
} [41]-[43]; Hills v Niksun Inc [2016] EWCA Civ 115 (CA) [33]-[35]. For detailed consideration of bases on which the court may find that a decision is unreasonable, see Varuhas ( $\mathrm{n} 32$ ).

${ }^{75}$ Braganza at [54]-[57] (Lord Hodge) and [18] and [32] (Lady Hale) but see Lord Neuberger and Lord Wilson's scepticism at [104]. For detailed consideration of the variables of judicial review, see Varuhas, n 32 above.

${ }^{76}$ Braganza at [18] (Lady Hale) and [54]-[57] (Lord Hodge).

77 Braganza at [56]-[57] (Lord Hodge).

78 ibid; Lord Hodge in Braganza at [54] drew a distinction between a decision about the payment of a death benefit and the assessment of whether an employee is entitled to a discretionary bonus.

${ }^{79}$ Braganza at [32] (Lady Hale); [54]-[55] (Lord Hodge) but see Lord Neuberger and Lord Wilson at [104] and [126]. 
are given greater latitude to make decisions that they perceive to be in their own interests. ${ }^{80} \mathrm{In}$ Paragon Finance PIc v Pender, ${ }^{81}$ the Court of Appeal held that exercising a discretion to raise interest rates in a rational way did not require '... that a lender may not, for a genuine commercial reason, adopt a policy of raising interest rates ... A commercial lender is ... free to conduct its business in what it genuinely believes to be its best commercial interest. ${ }^{82}$ So it was in another case that a lender could exercise a similar discretion for the purpose of managing its own financial difficulties. ${ }^{83}$

In contrast, where the contract is 'relational ${ }^{84 \prime}$ or involves a personal relationship or there is an inequality of bargaining power between the parties, such as a contract of employment, this is likely to justify more intense scrutiny of the decision. ${ }^{85}$ This owes to there being a higher risk of abuse through the right-holder taking advantage of the weaknesses of the other party. Similarly, the review is more rigorous where the decision could have a serious impact on the other party or the right-holder has the financial means and sophistication to make an informed decision. On the facts of Braganza, the discretion was contained in an employment contract, there was significant imbalance between the parties, ${ }^{86}$ the exercise of the discretion led to the family of the deceased being deprived of a death benefit with potentially serious consequences for them, ${ }^{87}$ and the right-holder, $\mathrm{BP}$, was a large company with access to extensive legal and other advisory services. ${ }^{88}$ These factors all militated in favour of stricter scrutiny and the need for cogent evidence that the decision was made on a properly informed basis, ultimately resulting in the decision being set aside.

\section{A High Bar for Intervention}

The high bar set by the court for impugning a decision is a further indicator that the review being undertaken is concerned with abuse. Something 'must have gone badly wrong', ${ }^{89}$ which is true only in extreme cases lying at the far end of spectrum. ${ }^{90}$ There is no requirement that the right-holder reach a decision that is objectively reasonable. As the Supreme Court made clear in Braganza, the court is not concerned with the substance or reasonableness of the decision. ${ }^{91}$ It will refrain from dictating

\footnotetext{
${ }^{80}$ Bridge, $\mathrm{n} 32$ above, 231.

81 [2005] EWCA Civ 760 (CA).

82 At [120] The italicised words are italicised in the judgment.

83 Paragon v Nash [2002] 1 WLR 685 (CA).

${ }^{84}$ The nature of 'relational contracts' and whether they are an established category of contract has been the subject of debate in the literature: see for example H Collins, 'Is a Relational Contract a Legal Concept?' in S. Degeling, J. Edelman, J. Goudkamp (eds) Contract in Commercial Law (London: Thomson Reuters, 2016); Z. X. Tan, 'Disruptive Doctrine? Revisiting the Doctrinal Impact of Relational Contract Theory' Legal Studies 39 (2019) 98. In Bates v Post Office Ltd (No 3) [2019] EWHC 606 (QB), Fraser J held that it is an established concept in the case law at [702]. Key features of relational contracts appear to be a long-term relationship, substantial investments made by both parties, and expectations of cooperation, loyalty, mutual trust and confidence: see Yam Seng Pte Ltd v International Trade Corp Ltd [2013] EWHC 111 (QB); Bristol Groundschool Ltd v Intelligent Data Capture Ltd \& Ors [2014] EWHC 2145 (Ch); D\&G Cars Ltd v Essex Police Authority [2015] EWHC 226 (QB); and more recently see Bates v Post Office Ltd (No 3) [2019] EWHC 606 (QB) in which Fraser J set out criteria to identify relational contracts at [725].

${ }^{85}$ Braganza at [18] and [36] (Lady Hale) and [54]-[57] (Lord Hodge) but see Lord Neuberger and Lord Wilson at [104].

${ }^{86}$ Braganza at [18] (Lady Hale); [54]-[57] (Lord Hodge).

${ }^{87}$ Braganza at [36] (Lady Hale); [54]-[57] and [61] (Lord Hodge).

${ }^{88}$ Braganza at [57] (Lord Hodge).

89 J. Morgan, 'Resisting Judicial Review of Discretionary Contractual Power' [2015] LMCLQ 484, 486.

${ }^{90}$ Any intervention is confined to extreme cases that are 'so outrageous in [their] defiance of reason that it could be characterised as perverse': Jani-King (GB) Ltd v Pula Enterprises Ltd [2007] EWHC 2433 (QB) [34].

${ }^{91}$ Braganza at [30] (Lady Hale); [52] (Lord Hodge); Socimer International Bank Ltd v Standard Bank London Ltd [2008] Bus LR 1304 (CA) [57] (Rix LJ).
} 
how the discretion should be exercised or substituting its own view. ${ }^{92}$ From the perspective of the right-holder, the standard is undemanding ${ }^{93}$ thus preserving their autonomy.

Being concerned only with decisions that are egregious, it is rare for the court to impugn the exercise of a discretion. Brooke $\sqcup$ said in Ludgate Insurance Co Ltd $v$ Citibank $N A^{94}$ that 'it is very well established that the circumstances in which a court will interfere with the exercise ... of a contractual discretion ... are extremely limited' ${ }^{95}$ As well as Braganza and Abu Dhabi National Tanker Co v Product Star Shipping Ltd (No 2), a further example of the high bar being met is Mallone $\vee$ BPB Industries. ${ }^{96}$ Relying upon an 'absolute discretion' to limit the number of share options that could be exercised by former employees, the company directors set the number at zero for an employee who had been dismissed. It was held by the Court of Appeal that this was irrational. No reason was given for the decision, which was found to have been made before the meeting in which it was supposed to be considered. Weight had also been placed on the entirely irrelevant factor that the employee had been awarded compensation in respect of his dismissal by an employment tribunal. ${ }^{97}$

\section{The difficulty in excluding the review jurisdiction of the court}

That abuse is the true determinant in contractual discretion cases is consistent with and even helps to explain the approach of the court where the parties have attempted to exclude the review jurisdiction over how the discretion is exercised. This is permissible in principle but difficult in practice. As Jackson $\sqcup$ said in Mid Essex Hospital Services NHS Trust v Compass Group UK and Ireland, ${ }^{98}$ the implied term that a discretion cannot be exercised in an arbitrary, capricious or irrational manner 'is extremely difficult to exclude, although I would not say it is utterly impossible to do so...'. It will not be enough, for example, for the parties to use the words 'absolute discretion' or couch the discretion in absolute terms. ${ }^{99}$ The court has however declined to interfere where there is not a true discretion because the power involves no evaluation; ${ }^{100}$ a binary choice or a selection from a range of options; ${ }^{101}$ in relation to certain specific contractual rights such as the right to terminate ${ }^{102}$ (possibly because they are perceived to involve a binary choice $\left.{ }^{103}\right)$; and in contracts that contain precise rules regulating the

\footnotetext{
92 Paragon Finance $v$ Nash [2002] 1 WLR 685 (CA), in which the Court of Appeal was only willing to limit the power of the bank to raise interest rates in extreme cases: 'it is one thing to imply a term that a lender will not exercise his discretion in a way that no reasonable lender, acting reasonably, would do ... It is quite another matter to imply a term that the lender would not impose unreasonable rate' [41] per Dyson LJ). But see Bridge, n 32 above, 239-240.

${ }^{93}$ Bridge, n 32 above, 248; E. McKendrick, 'Good Faith in Contract Performance-England' in L. A. di Matteo and M. Hogg (eds) Comparative Contract Law, British and American Perspectives (Oxford: OUP, 2016) 196, 200.

94 [1998] Lloyd's Rep IR 221.

${ }^{95}$ At [35]-[36].

96 [2002] ICR 1045 (CA).

${ }^{97}$ Flaws in the decision-making process also justified the court interfering in Watson v Watchfiners.co.uk [2017] EWHC 1275 (Comm), BHL v Leumi ABL Ltd [2017] EWHC 1871 (QB), and Hills v Niksun [2016] EWCA Civ 115 (CA). 98 [2013] EWCA Civ 200.

${ }_{99}$ As in Mallone v BOB Industries Ltd [2002] ICR 1045 (CA) and Clark v BET Plc [1997] IRLR 348 where the rightholder had an 'absolute discretion'; Hills v Niksun [2016] EWCA Civ 115 (CA) ('absolute discretion'; 'solely decided by').

100 Criticised in the literature: see for example Bridge, n 32 above, 229: 'a difficult line has to be drawn between reviewable discretionary powers and what have been referred to as absolute rights'; Varuhas, $\mathrm{n} 32$ above.

${ }^{101}$ Mid Essex Hospital Services NHS Trust v Compass Group UK and Ireland [2013] EWCA Civ 200 [83] and [91]; Monde Petroleum SA v Westernzagros Ltd at [83]; Monk [54]-[60], [64]; British Telecommunications plc v Telefonica O2 UK Ltd [2014] Bus LR 765, [37] per Lord Sumption.

102 Most recently, TAQA Bratani Limited and Others v RockRose UKCS8 LLC [2020] EWHC 58 (Comm).

${ }^{103}$ Or because they are already subject to 'pre-existing tests governing when the power to terminate arises, which balance parties' interests and ... superimposing the Braganza principles would cut across that balance': Varuhas, n 32 above.
} 
operation of the discretion and the decision-making process and which make provision for how abuse should be dealt with. ${ }^{104}$

Judicial resistance to the exclusion of the court's review jurisdiction over the exercise of contractual discretionary powers is unsurprising if, as this article contends, it is founded on abuse of rights. It would be intolerable for the court to be forced to stand aside, impotent to prevent abuse, even though this might be expressly intended by the contract. Such an outcome would prevent the application of even the most fundamental standards such as honesty and rationality, which would give rise to similar objections as attempting to exclude liability for deceit, ${ }^{105}$ which is impermissible.

Some have questioned why the implied term cannot be more readily excluded given that terms implied in fact serve to give effect to the unexpressed intentions of the parties and therefore ordinarily cannot be implied when in conflict with an express term of the contract. ${ }^{106}$ It is said that any attempt to exclude the court's control over how a discretion is exercised should therefore prevail and be given effect, which would promote the freedom of contract and certainty that are prized by commercial parties. ${ }^{107}$

Whilst the implied term has been rationalised as based in fact, a more realistic view is that it owes to a rule of wider importance. The clear aim of protecting vulnerable parties against abusive selfinterest, which is key to both the test and its application, suggests that the review jurisdiction is rooted in broader considerations of fairness, justice and policy, not simply the unexpressed intention of the parties. ${ }^{108}$ This is also discernible from the close similarity with public law principles, which undisguisedly give effect to externally imposed standards rather than the will of the parties. As Collins has said, 'the borrowing or transplant of terminology from public law in the test of irrationality is particularly striking ..., for it abandons any pretence that the courts are merely enforcing terms that the parties agreed explicitly or by necessary implication'. ${ }^{109}$

This analysis is also consistent with the term being implied routinely in a variety of contexts ${ }^{110}$ and its description in the cases as imposing 'standard limits, ${ }^{111}$ 'the test' ${ }^{112}$ and 'the Braganza duty'. ${ }^{113}$ Extra-judicially, Leggatt $L$ has gone as far as to say that the implied term is 'used to state a rule of law' and 'has become a general default rule'. ${ }^{114}$ These are all pointers towards the control of the court being founded on a rule of broader significance and application, which explains why it is difficult to exclude. This rule, it is submitted, is one that prevents the abuse of rights.

\section{Abuse of rights and good Faith}

An alternative explanation of the review jurisdiction over contractual discretionary powers is as an aspect of the general principle that contracts must be performed in good faith. Judicially and extrajudicially, ${ }^{115}$ Leggatt J (as he then was) has pointed to the developing case law on discretionary powers

\footnotetext{
${ }^{104}$ Mid Essex Hospital Services NHS Trust v Compass Group UK and Ireland [2013] EWCA Civ 200.

105 Bridge, n 32 above, 228-229.

${ }^{106}$ Duke of Westminster v Guild [1985] QB 688, 700.

107 J. Morgan, 'Against Judicial Review of Discretionary Contractual Powers' [2008] LMCLQ 230, 236-237.

108 E. Peden 'Policy Concerns Behind Implications of Terms in Law' (2001) 117 LQR 459.

${ }^{109}$ Collins, n 50 above; See also Hooley, n 16 above, 72.

110 See Varuhas, n 32 above.

${ }^{111}$ Socimer International Bank Ltd v Standard Bank London Ltd [106] and [111] (Rix LJ).

112 Braganza at [28]-[29] (Lady Hale).

${ }^{113}$ BHL v Leumi ABL Ltd [2017] EWHC 1871 (QB) at [40], [44], [111], [113].

${ }^{114}$ Leggatt, $\mathrm{n} 40$ above, [50]; on the debate as to whether the term is implied in law or in fact, see Varuhas, n 32 above: 'even if the term began life as a factual implication, its now routine implication, and core features, suggest it has crystallised into a legal implication'.

115 Yam Seng Pte Ltd v International Trade Corporation Ltd [2013] EWHC 111 (QB) and MSC Mediterranean Shipping Co SA v Cottonex Anstalt [2015] EWHC 283 (QB) [96]; Leggatt, n 40 above, [51]. See also Hooley, n 16 above.
} 
as evidence of the emergence of a duty of good faith in English law. ${ }^{116}$ This duty is said to be objective, to be judged by the standard of 'reasonable and honest people'. ${ }^{117}$ It includes, as a minimum, the core value of honesty but can also require adherence to reasonable commercial standards of fair dealing. ${ }^{118}$ Being based on the presumed intention of the parties, it arises by implication, giving effect to their expectations and the agreed common purpose of the contract. ${ }^{119}$

It is submitted that abuse of rights offers a better explanation for these cases. Whilst good faith might seem to explain some, it is irrelevant in others. This raises the possibility of there being another explanation. The cases that good faith seems apt to explain are mainly those where there is dishonesty or deliberate exploitation. As Professor Stapleton has shown, the core purpose of good faith is to restrain the advertent pursuit of self-interest where that would be unconscionable through being dishonest or deliberately contradictory or exploitative of dominance over another. ${ }^{120}$ The presence of dishonesty or deliberate exploitation that characterises the failure to act in good faith will invariably lead to the exercise of a contractual discretion being impugned. However, these factors would also enable a finding that the discretion has been abused. To this extent the doctrines overlap.

Yet the review undertaken by the court to prevent abuse extends beyond dishonesty or deliberate exploitation. It is also concerned with the rationality of the decision, which is clearly distinct from honesty and good faith. An exercise of discretion can be irrational and therefore abusive yet in good faith. As Rix $\amalg$ said in Mallone $v$ BPB Industries, ${ }^{121}$ the right-holder 'may act irrationally while being honest'. ${ }^{122}$ In Braganza, the Supreme Court recognised that BP had carried out its investigation in good faith and had not acted unfairly. ${ }^{123}$ Nevertheless, the conclusion reached by BP that the claimant's husband died by suicide such that she was not entitled to a contractual death benefit was held to be irrational and impugned. Therefore, in some circumstances, the court imposes a different, more onerous standard than good faith. ${ }^{124}$

In other circumstances, good faith has the potential to impose a greater burden on the rightholder than the rule preventing the abuse of the discretionary power. ${ }^{125}$ If understood to necessitate

\footnotetext{
116 The inherent difficulties with the principle of good faith proposed by Leggatt $J$ are well-documented in burgeoning academic literature on the issue: S. Whittaker, 'Good Faith, Implied Terms and Commercial Contracts' (2013) 129 LQR 463; E. Granger, 'Sweating over an Implied Duty of Good Faith' [2013] LMCLQ 418; H. Collins, 'Implied Terms: The Foundation in Good Faith and Fair Dealing' [2014] CLP 297; M. Bridge, 'Limits on Contractual Freedom' (2019) The Chinese Journal of Comparative Law 387; M. Bridge, 'Does Anglo-Canadian Contract Law Need a Doctrine of Good Faith?' (1984) 9 Canadian Bus LJ 385. Good faith as a general organising principle has also been rejected by the courts: Mid Essex Hospital Services NHS Trust v Compass Group UK and Ireland [2013] EWCA Civ 200 at [105]; Greenclose Ltd v National Westminster Bank Plc [2014] EWHC 1156 (Ch) at [150]; but see Bates v Post Office Ltd (No 3) [2019] EWHC 606 (QB) at [702]ff.

117 Yam Seng at [144] and [150]

118 Yam Seng at [137]-[152]; for a more recent decision of Leggatt LJ (sitting in the High Court) on good faith, see Al Nehayan v Kent [2018] EWHC 333 (Comm) at [167]-[176]; see also Leggatt J, n 40 above, [30]. There has been controversy over the meaning of good faith, in particular whether it is mainly concerned with issues of honesty or wider in scope. This is illustrated by the recent criticism of Chitty on Contracts, 33rd ed. (London: Thomson Reuters, 2019) by Fraser J in Bates v Post Office Ltd [2019] EWHC 606 (QB) at [708]-[711] for limiting good faith to honesty. He said 'there is more to a duty of good faith than a requirement to act honestly ... the parties must refrain from conduct which in the relevant context would be regarded as commercially unacceptable by reasonable and honest people'.

${ }^{119}$ Yam Seng at [148]-[149]; Leggatt, $\mathrm{n} 40$ above, [41] and [61].

120 J. Stapleton, 'Good Faith in Private Law' (1999) 52 CLP 1, 7-9 and 35-6.

121 [2002] ICR 1045 (CA).

${ }^{122}$ At [39]; See also Westlb Ag v Nomura Bank International Plc [2010] EWHC 2683 (Comm) [81] per Teare J: 'This was an irrational mistake but I do not consider that it was made dishonestly'.

${ }^{123}$ Braganza at [63] (Lord Hodge).

${ }^{124}$ Bridge, n 116 above, 389: 'some contractual decision may fail to comply with ... standards [of capricious', arbitrary', 'irrational'] of decision-making and yet not fail a test of good faith'.

${ }^{125}$ Bridge, n 32 above, 233.
} 
adherence to reasonable commercial standards of fair dealings as Leggatt J suggested, ${ }^{126}$ it could even require him to behave in a way that is objectively reasonable. ${ }^{127}$ Yet there is no such requirement and the standard is set much lower, largely preserving the right-holder's freedom to choose.

The abuse of rights rule also has a distinct purpose, even if there is some overlap with good faith. This is to prevent the misuse of a power, whether or not deliberate. The fundamental question is whether the power has been exploited, frustrated or exercised improperly. This does not require moral judgment. It is designed to prevent abuse rather than fulfilling wider ambitions of promoting positive standards of behaviour. This might also result but it is an incidental and indirect consequence, not an objective in its own right.

\section{THE NEW RULES ON PENALTIES}

It is submitted that the same rule against the abuse of rights also underlies the new law on penalties laid down in Cavendish Square Holding BV v Talal El Makdessi. ${ }^{128}$ In that case, the Supreme Court held that, in order to be valid, a damages clause must serves a legitimate interest in performance of the injured party and impose a detriment that is not extravagant, exorbitant or unconscionable in comparison with the interest protected. Only where the clause stipulates a punishment will it be unenforceable. This is a departure from the previous rule under which any clause that went beyond compensation was unenforceable without any enquiry into whether or not it was objectionable. ${ }^{129}$

It will be shown that, as when the court reviews contractual discretionary powers, the mischief that the new rule against penalties seeks to address is abuse. The court undertakes a nuanced and evaluative enquiry into whether there is an abuse of the right ${ }^{130}$ or freedom to fix the sum payable on breach. The abuse is in stipulating a sum that goes beyond compensation to the point of being unconscionable where there is no legitimate interest.

The relevance of abuse to the rule against penalties is discernible from a number of different indicators. These are the rationale for the rule, the test that is applied and the high bar for the court to intervene, which filters out only the most egregious cases. It is however less apparent than with contractual discretionary powers, not having been expressly referred to in Makdessi or subsequent cases, and because damages clauses operate differently from contractual discretions. Notably, the right or freedom being abused inheres in the broader right to create mutual rights and duties by agreement, ${ }^{131}$ with any abuse occurring and being assessed at the time the contract is made and involving both parties. ${ }^{132}$ This contrasts with the power to exercise a contractual discretion, which is

\footnotetext{
${ }^{126}$ Yam Seng; Bates v Post Office Ltd [2019] EWHC 606 (QB).

${ }^{127}$ Bridge, $\mathrm{n} 32$ above, 233: the 'requirement to act in accordance with good faith and fair dealing, transcending mere honesty, should be seen as imposing on the party subject to it a higher standard of conduct than is imposed by the standard governing the exercise of discretion. It may even amount to a requirement to behave in an objectively justifiable way'.

${ }^{128}$ With its conjoined appeal ParkingEye Ltd v Beavis [2016] AC 172.

${ }^{129}$ Note however that there was growing recognition that the pre-emptive invalidation of all damages clauses to neutralise occasional unfairness was a crude and inexact solution and the courts had shown growing tolerance towards large but not oppressive clauses: Philips Hong Kong Ltd v The AG of Hong Kong (1993) 61 BLR 41 (PC); Murray v Leisureplay plc [2005] EWCA Civ 963 (CA).

130 The terms 'right' and 'freedom' are used in this section of the article in the same way as in the case law to describe the ability of the parties to stipulate the consequences of breach. See for example Lord Diplock using the term 'right' in Robophone Facilities Ltd v Blank [1966] 1 WLR 1428, 1446:

'But the right of parties to a contract to make such a stipulation is subject to the rule of public policy that the court will not enforce it against the party in breach if it is satisfied that the stipulated sum was not a genuine estimate of the loss...'.

${ }^{131}$ The rule against penalties is therefore concerned with the product of the bargaining process and the validity of the disputed clause.

132 Both contracting parties appear to participate in the abuse in that both agree to the allegedly abusive clause, which seems a surprising analysis. However, as the Supreme Court in Makdessi recognised, in many cases, the
} 
conferred by the agreement itself, arises during the life of the agreement and belongs unequivocally to, and is abused by, one party alone. It is also generally not connected with the occurrence of a breach. However, none of these differences should detract from the centrality of preventing abuse in the context of penalties.

\section{The protection against abuse through the prohibition of contractual punishment}

The juridical basis for the rule against penalties has for a long time been a source of some uncertainty. This was openly recognised in the statement of Lord Diplock in Robophone Facilities Ltd v Blank ${ }^{133}$ that 'I make no attempt, where so many others have failed, to rationalise this common law rule'. ${ }^{134}$ The most recent word on the subject was in Makdessi, where the Supreme Court attributed the rule to the public policy of prohibiting punishment. As Lord Hodge stated, it is based on the 'public policy that the courts will not enforce a stipulation for punishment for breach of contract'. ${ }^{135}$ There is punishment where one party imposes on the other a detriment that is extravagant or unconscionable in comparison with the legitimate interest being served. The question of enforceability, as Lord Neuberger and Lord Sumption stated, should depend on 'whether the means by which the contracting party's conduct is to be influenced are 'unconscionable' or ... 'extravagant' by reference to some norm' ${ }^{136}$ According to Lord Mance, the rule 'in its core exists to restrain exorbitant or unconscionable consequences following from breach'. ${ }^{137}$

Whilst these statements make no explicit reference to abuse, they nonetheless expose that, in essence, the rule serves to ensure that the right or freedom to agree upon the consequences of breach is not misused to overburden or exploit the defaulting party. It is a perversion of the purpose of a damages clause - to enable the parties to achieve contractual certainty ${ }^{138}$ - for one party to profit by subjecting the other to extortionate demands and severe hardship. Punishment, through the provision of exorbitant secondary obligations, is a misuse of the right or freedom or, differently put, not a permissible use of contract. By refusing to enforce the clause, the court curtails and protects the defaulting party from such abusive self-interest.

Nowhere is this more evident than in one of the main reasons cited by the Supreme Court in Makdessi for declining to abrogate the rule: to protect parties that are vulnerable and in a weaker bargaining position. ${ }^{139}$ Whilst recognising that legislation to control unfair terms in consumer contracts has reduced the need for the rule to protect consumers, the Supreme Court said that it does nothing for vulnerable parties to commercial contracts. Yet 'there remain significant imbalances in negotiating power in the commercial world. Small businesses often contract with large commercial entities and have little say as to the terms of their contracts'. ${ }^{140}$ These businesses share 'many of the characteristics of consumers which are thought to make [them] worthy of legal protection' but do not benefit from the same statutory protections. ${ }^{141}$ The potential for oppression of these parties, who are the most susceptible to abuse, was perceived to be sufficiently great to warrant judicial intervention.

\section{Various mechanisms for preventing abuse}

clause is effectively imposed by the stronger party on the weaker party: at [35]-[38] (Lord Neuberger and Sumption); [167] (Lord Mance); [257]-[262] (Lord Hodge).

133 [1966] 1 WLR 1428.

134 At 1446.

${ }^{135}$ Makdessi at [243] (Lord Hodge).

${ }^{136}$ Makdessi at [31] (Lord Neuberger and Sumption).

${ }^{137}$ Makdessi at [162] (Lord Mance).

${ }^{138}$ Robophone Facilities Ltd v Blank [1966] 1 WLR 1428, 1446, 1447.

${ }^{139}$ Makdessi at [38] (Lord Neuberger and Sumption); [167] (Lord Mance); [262] (Lord Hodge).

140 Makdessi at [262] (Lord Hodge).

${ }^{141}$ Makdessi at [38] (Lord Neuberger and Sumption). 


\section{Overcompensation Must be Justifiable and Set at a Proportionate Level}

The test for punishment introduced by the Supreme Court in Makdessi sets two safeguards against abuse: the detriment must serve a 'legitimate interest in performance' and not be 'extravagant, exorbitant and unconscionable' in nature.

The first of these safeguards - the legitimate interest in performance ${ }^{142}-$ seeks to prevent abuse by requiring the beneficiary of the clause to show some acceptable basis or justification for the purported entitlement to an over-compensatory sum upon breach. There must be rational reasons for the right or freedom to agree to a damages clause being exercised in this way that justify more robust protection of performance than is obtainable through compensation. In effect, the beneficiary of the clause cannot recover more than their loss without a good reason.

The second safeguard against abuse is achieved by prohibiting extreme or disproportionate levels of overcompensation. It asks 'whether, assuming [a legitimate] interest to exist, the provision made for the interest is nevertheless in the circumstances extravagant, exorbitant or unconscionable'. ${ }^{143}$ The agreed sum cannot be substantially more than what is necessary to protect the wider interests of the beneficiary. This is designed to catch grossly excessive provisions that are out of proportion in nature and impact with the protected interest. ${ }^{144}$

These requirements were satisfied and there was no abuse on the facts of Makdessi itself. This was because the disputed non-compete covenants, which went beyond compensation, had been inserted so as to ensure the loyalty of the sellers and protect the goodwill of the business, which were vitally important to the buyer. A significant proportion of the contract price was attributable to them since the value of the business was mainly founded on its goodwill, without which it would be worth much less. Breach of the covenants would defeat the buyer's commercial objectives in acquiring the business. The buyer therefore had a legitimate interest in maintaining the goodwill and the detriment was not disproportionate.

\section{Varying the Level of Scrutiny According to the Risk of Abuse}

As with the review undertaken by the court over contractual discretionary powers, the varying degrees of scrutiny applied by the court when reviewing damages clauses are a pointer to the protection against abuse. The extent of the scrutiny in any given case will depend on a range of factors such as the nature of the contract, the circumstances in which it was negotiated ${ }^{145}$ and the attributes of the parties. As a broad rule of thumb, where a party's bargaining power and capacity to protect its interests are strong and the risk of abuse is low, the court will be less inclined to review a damages clause making that party liable. Conversely, the weaker is a party's bargaining position, the more intensive will be the review. In this way, the level of scrutiny varies according to the risk of abuse. ${ }^{146}$

The Supreme Court in Makdessi made clear that where the contract is between sophisticated commercial parties that have negotiated at arm's length, the court will be slow to interfere. As Lord Neuberger and Lord Sumption said, 'the circumstances in which the contract was made are not entirely irrelevant. In a negotiated contract between properly advised parties of comparable bargaining power, the strong initial presumption must be that the parties themselves are the best judges of what is legitimate in a provision dealing with the consequences of breach'. ${ }^{147}$ In Makdessi

\footnotetext{
142 S. Rowan, 'The 'legitimate interest in performance' in the law on penalties' (2019) 78 CLJ 148.

${ }^{143}$ Makdessi at [152] (Lord Mance); see also [255] (Lord Hodge); [293] (Lord Toulson).

${ }^{144}$ Makdessi at [32] (Lord Neuberger and Lord Sumption); [249] and [255] (Lord Hodge).

${ }^{145}$ Cargill International Trading Pte Ltd v Uttam Galva Steels Ltd [2019] 2 WLUK (QB) 481.

146127 Hobson Street Ltd v Honey Bees Preschool Ltd [2020] NZSC 53 at [90] summarising the position in Makdessi: 'On the other hand, where there is evidence of unequal bargaining power, or where one party is not legally advised, a court will scrutinise more closely the innocent party's claims as to the interests protected, and also the issue of proportionality'

${ }^{147}$ Makdessi at [35] (Lord Neuberger and Lord Sumption).
} 
itself, weight was given to the fact that the contract had been the subject of detailed negotiations for many months between sophisticated commercial parties, dealing with each other on an equal basis with the benefit of specialist legal advice.

The rationale for the 'strong initial presumption' is that contract terms that are genuinely negotiated at arm's length by sophisticated parties advised by experts are inherently unlikely to be abusive. Such parties are regarded as capable of protecting their own interests. If they consider that compensation is inadequate and require a more robust remedy, they should be taken to understand the interests at stake and the implications. ${ }^{148}$ This approach preserves freedom of contract and provides certainty that the clause will be enforced, which commercial parties value.

The practical effect is that sophisticated commercial parties are treated differently and it is more likely that their damages clauses will be enforceable, even if over-compensatory. They will be presumed to have good business reasons for requiring performance as opposed to compensation. If the court interferes, it does so at risk of imposing its own views over those of the parties as to what interests are deserving of protection. As one commentator has put it, 'the 'strong initial presumption' approach suggests that affirmative evidence of procedural fairness may weigh heavily enough to turn a substantively dubious clause into one that passes the validity test'. ${ }^{149}$

In contrast, for parties not belonging to this class, there is a higher hurdle to satisfy. ${ }^{150}$ The test is applied 'in a less generous way'. ${ }^{151}$ Where there is an inequality of bargaining power or one of the parties is otherwise able to impose terms, the court will be more willing to interfere. The beneficiary of the clause is "less likely to get away with a provision that is disproportionate to what it needs than if there is no effective bargaining pressure from the other party'. ${ }^{152}$ This owes to there being a higher risk of abuse through the exploitation of the vulnerability of the weaker party. In these situations, the courts seek to 'strike a balance between the competing interests of freedom of contract and protection of weak contracting parties'. ${ }^{153}$

\section{A High Bar for Intervention}

The high bar that is set by the court for invalidating a damages clause is a further indicator that the jurisdiction is concerned with abuse. It is designed to catch extreme and egregious cases at the far end of the spectrum. ${ }^{154}$ If there is some basis for overcompensation and the agreed amount is not 'wholly disproportionate', ${ }^{155}$ there is reluctance to find that a clause is penal. ${ }^{156}$ In Makdessi, it was emphasised that the court should not impose 'too stringent a standard'. ${ }^{157}$ As Lord Hodge said, 'I am not persuaded that the rule against penalties prevents parties from reaching sensible arrangements to fix the consequences of a breach of contract ... The criterion of exorbitance or unconscionableness should prevent the enforcement of only egregious contractual provisions'. ${ }^{158}$

This is illustrated in the cases, where damages clauses that stipulate high amounts have been held to be enforceable. In Makdessi, for instance, the reduction in the contract price following breach of the non-compete covenants was in the millions of dollars, yet it was held to serve a legitimate

\footnotetext{
${ }^{148}$ Makdessi at [33]-[35] (Lord Neuberger and Lord Sumption).

${ }^{149}$ A Summers, 'Unresolved Issues in the Law on Penalties' [2017] LMCLQ 95.

150127 Hobson Street Ltd v Honey Bees Preschool Ltd [2020] NZSC 53 at [90].

${ }^{151}$ Chitty on Contracts, n 118 above, at [26-227].

152 Chitty on Contracts, n 118 above, at [26-229].

${ }^{153}$ Makdessi at [35] (Lord Neuberger and Lord Sumption) citing Mason and Wilson JJ in the AMEV-UDC Finance Ltd v Austin (1986) 162 CLR 170, 194.

${ }^{154}$ Makdessi at [32] (Lord Neuberger and Lord Sumption): the detriment must be 'out of all proportion to any legitimate interest of the innocent party'; [249] and [255] (Lord Hodge).

${ }^{155}$ Makdessi at [226] (Lord Hodge).

156 Makdessi at [33] and [152]; Signia Wealth Ltd v Vector Trustees Ltd [2018] EWHC 1040 (Ch) at [74]. Chitty on Contracts, n 118 above, at [26-195].

157 Makdessi at [248] (Lord Hodge).

${ }^{158}$ Makdessi at [266].
} 
interest and not to be extravagant or unconscionable. Similarly, in BHL v Leumi ABL Ltd, ${ }^{159}$ a collection fee in a receivables finance agreement of up to $15 \%$ of the sums collected was held not to be extortionate, even if high.

The high bar is also apparent in the relatively generous approach that the courts have taken to the question of what constitutes a legitimate interest. When answering this question, they have been willing to have regard not only to the interests of the party exercising the right but also those of third parties or the public in general. ${ }^{160}$ In ParkingEye Ltd v Beavis, ${ }^{161}$ the Supreme Court held that the management company of a car park had a legitimate interest in enforcing an $£ 85$ parking charge against a driver who had overstayed the two-hour parking limit. Although the fine was not compensatory and was designed to deter motorists from overstaying, the management company had a legitimate interest in the efficient use of the parking spaces for the benefit of other motorists, as well as in discharging its obligation to the owners of the car park and generating an income stream from the charges to meet its operating costs.

Being concerned with egregious cases, findings of abuse are rare. One example is Vivienne Westwood Ltd $\vee$ Conduit Street Development $L t d .{ }^{162}$ The landlord and tenant of retail shop premises had agreed in a side letter to the lease to a reduction in the rent payable under the lease. If the tenant defaulted in any way, the landlord could terminate the side letter and the rent payable would revert back to its original level. As a result of some confusion, the tenant failed to make a monthly rent payment and the question arose as to whether the landlord's right to terminate the side letter was unenforceable.

The court held that the disputed clause was not valid. This was for two reasons. First, it applied regardless of the nature and seriousness of the breach and its consequences, and therefore even when uncompensated loss was unlikely to follow. Second, the increase in the rent was exorbitant and unconscionable. It was payable in addition to interest on overdue payments, costs incurred by reason of the breach and compensatory damages for loss. It was also due for the remainder of the term and with retroactive effect from the commencement of the lease. ${ }^{163}$ This could give rise to a very substantial and disproportionate financial detriment as a result of what could be a minor breach with no serious consequence for the lessor.

Another example is First Personnel Services Ltd v Halfords $L t d,{ }^{164}$ in which an interest rate of $2 \%$ on late payment of wages invoices in a contract for the supply of temporary workers was held to be exorbitant. It was 'so completely out of line with commercial norms applicable at the time' and also the rate prescribed under the Late Payment of Commercial Debts (Interest) Act 1998. No justification was proffered by the injured party as to why a rate so far above the normal commercial level was required to support the legitimate interest in punctual payment.

\section{THE RELEVANCE OF 'ABUSE'}

It has been shown that the control exercised by the court over contractual discretionary powers and penalty clauses protects against the abuse of rights. This is given effect differently, with the control in the former context being concerned with how an agreed contractual power is exercised and in the latter context with the agreement of a damages clause that is excessive. These distinctions should not however obscure that, in both contexts, whether or not there is abuse is determinative.

There are a number of significant parallels between the review undertaken by the court in these two contexts. The first is in their mutual purpose of protecting against unconscionable self-

\footnotetext{
159 [2017] EWHC 1871 (QB); see also Holyoake v Candy [2017] EWHC 3397 (Ch) at [485]-[486].

160 Rowan, n 142 above.

161 [2015] UKSC 17 (SC).

162 [2017] EWHC 350 (Ch).

163 ibid at [63]-[65] (Timothy Fancourt QC, sitting as a Deputy Judge of the High Court).

164 [2016] EWHC 3220 (Ch) [162]-[163]; see also Hayfin Opal Luxco 3 SARL v Windermere VII CMBS PIC [2016]

EWHC 782 (Ch) [140].
} 
interest. To limit the exercise of a power or freedom is necessary to prevent contracting parties from being unfairly overburdened. This is especially relevant where there is an imbalance of bargaining power in the contractual relationship, enabling the party in a superior position to exploit the weaknesses of the other.

A second parallel is in the tests and standards that apply. There is no requirement that the right-holder act reasonably. Rather, he must refrain only from exercising the right disingenuously, inconsistently with the purpose for which it was conferred (as agreed by the parties or set by the law) and the objectives of the contract, outside of its limits or for no legitimate reason. Any exercise of the right in these ways would be objectionable and impermissible. This serves to define what is meant by 'abuse'.

The standards are undemanding, being satisfied where the right-holder has acted with some proper basis or in a way that is justifiable. Abuse is therefore identified by examining the reason(s) (if any) for the exercise of the discretion or inclusion of the damages clause. The right-holder must be able to explain and substantiate these reasons. As Bridge has explained, 'self-interested actions must ... comply with a minimum level of justification'. ${ }^{165}$

A third parallel is that, observant of the interests in contractual freedom and certainty, the court tailors the level of scrutiny to the risk of abuse. This explains why parties to commercial contracts negotiating at arms' length who can generally look after their own interests are given greater latitude than others and court intervention is confined to egregious cases. The bar is high and intervention rare.

The parallels between the rules and approach of the court are substantive and seem unlikely to be a mere coincidence. Instead, they suggest that a wider principle, which seeks to prevent abuse, operates in these two contexts. The principle defines how the right can be exercised, setting the boundary between what is acceptable, which accounts for most cases, and what is unacceptable, which is relatively rare.

There are also clear parallels with at least one overseas jurisdiction where abuse of rights is recognised. France has a general doctrine of abuse of rights, and this serves to limit the exercise of contractual discretionary powers. ${ }^{166}$ The focus is on whether the discretion has been perverted. ${ }^{167}$ This has commonalities with the French administrative law doctrine of abuse of power (détournement de pouvoir). ${ }^{168}$ Relevant considerations include whether the discretion has been exercised within its proper limits, for its intended purpose, in pursuance of a legitimate interest ('intérêt légitime') and on proper grounds ('juste motif'). ${ }^{169}$

By way of example of the application of the doctrine to contractual discretionary powers, the Civil Code requires that a unilateral right to fix the contract price is not exercised abusively. ${ }^{170}$ If called

\footnotetext{
165 Bridge, n 116 above, 406.

${ }^{166}$ P. Stoffel-Munck, L'abus dans le contrat: Essai d'une théorie (Paris : LGDJ, 2000) ; M Fabre-Magnan, Droit des obligations, Contrat et engagements unilateral (Paris: PUF, 2010, $2^{\text {nd }}$ ed) 80-82 ; L Cadiet and P le Tourneau, 'Abus de droit', Répertoire de droit civil (Paris : Dalloz, 2015, 3rd edn).

167 Stoffel-Munck, n 166 above, [731].

168 G. Texier, 'L'abus de droit en matière de droit public', in J Mestre, L'abus dans le droit des affaires, Dr et Patr 2000/83, at 57ff; M. Hauriou commenting on CE 27 Feb 1903, S 1905.3.17; O. de David Beauregard-Berthier, 'La notion de détournement de procédure en droit administrative', Revue juridique, Lexis Nexis (2006) [9]; StoffelMunck, n 166 above, [731]; Cadiet and le Tourneau, n 166 above, [26].

${ }^{169}$ Stoffel-Munck, n 166 above, [634]-[802], in particular [783]-[789]; F. Chénedé, 'Les conditions d'exercice des prérogatives contractuelles' RDC 2010.709 at[14]; G. Courtieu, 'Arts 1382 a 1386 - Fasc 131-20: Droit à la réparation - Abus de droits et abus de pouvoirs' Lexis Nexis 19 juin 2005 at [26]-[47]; Dalloz, fiche d'orientation, 'I'abus de droit' (2019); Cadiet and le Tourneau, n 166 above, [27]-[29], [85]-[99] and [197].

170 In 'framework contracts' (contrat-cadre): new article 1164 of the French Civil code. See also new article 1165 of the Code.
} 
upon to do so, the right-holder must show that it has been exercised rationally ${ }^{171}$ and justify the price. Similarly, a principal was held to require a legitimate basis for exercising a power to terminate an agency contract, even though the power was expressed to be unilateral and to be exercised 'whenever [the principal] likes'. ${ }^{172}$ Nor could a landlord exercise a unilateral discretion to approve or reject a proposed assignee of the lease for a collateral purpose. ${ }^{173}$ This was also the case for an employer who had a unilateral discretion to terminate an employment contract at the end of the probation period. ${ }^{174}$

The relationship between abuse of rights and good faith has attracted attention in France. It has been described as 'close, even intimate' ${ }^{175}$ and the courts frequently refer to the principles interchangeably. ${ }^{176}$ However, at least in the context of contractual discretion, French commentators have increasingly drawn a distinction between the two principles, which they have shown to have different objectives. ${ }^{177}$ In assessing good faith, the court focuses on the conduct of the decisionmaker, making a moral and value judgment and seeking to promote minimum standards of conduct. The doctrine of abuse of rights focuses instead on whether the right has been perverted, intentionally or otherwise. As Stoffel-Munck has said, 'the question is not to determine whether a right has been perverted hypocritically, selfishly, with an intention to harm but rather to assess if it has been perverted if at all'. ${ }^{178}$

It is also widely recognised in France that the rules that regulate damages clauses are concerned with preventing abuse in the stipulation of the consequences of breach, even though neither the Civil Code nor the courts expressly refer to the abuse of rights. ${ }^{179}$ Whilst contracting parties are allowed to agree to liquidated damages clauses and penalty clauses, ${ }^{180}$ the Civil Code imposes limits where this results from abuse and leads to oppression. For sums that are 'manifestly excessive ${ }^{1}{ }^{181}$ the abuse can be curtailed by the court reducing the amount of the agreed penalty.

The same focus on abuse is perceptible in the equivalent rules in international commercial instruments such the UNIDROIT Principles of International Commercial Law, ${ }^{182}$ the Principles of

${ }^{171}$ F. Terré, P. Simler, Y. Lequette and F. Chénédé, Droit civil, Les obligations, (Paris : Dalloz 2018, 12 ${ }^{\text {th }}$ edn) [387]; O. Deshayes, T. Génicon and Y.-M. Laithier, Réforme du droit des contrats, du régime general et de la preuve des obligations (Paris : LexisNexis 2018, $2^{\text {nd }}$ edn) 313-316.

172 Com 3 July 2001, No 98-16.691, D 2001 AJ.2826; Civ 1, 28 Jan 2003, Bull civ 2003.I.27; Com 14 Oct 1997 No 95-16.937; Com 10 March 1976, D 1976 Somm 49. noted by P. Stoffel-Munck.

${ }^{173}$ Req 16 Nov 1927 DP 1928.I. 61 Rapport Bricourt ; Com, 19 Feb 1963, JCP 1963.II.13299; CA Lyon 17 mai 2001 RJDA 2001, No 1204; Com 3 Nov 2004, No 02-17.919, RDC 2005.288 noted by P. Stoffel-Munck; Com 5 Oct 2004, No 02-17338; Com 19 Feb 1963, JCP 1963.II.13299; Com 2 July 2002, No 01-12.685, D 2003.93, noted by D. Mazeaud; RDC 2003.50 noted by P. Stoffel-Munck; Com 4 Oct 2004, No2-17338: Civ 3, 14 April 1982, JCP 1982.IV.217; CA Paris 7 April 1995, Rev societies 1995.771.

${ }^{174}$ Civ 3, 11 May 1976, D 1978.269 noted by J.J. Taisne; for a finding that the exercise of a mobility clause in an employment contract is abusive, see Civ 3, 2 Feb2005, Bull Civ 2005, III, No 24; Paris 24 March 1999, D 1999.IR 141.

175 Stoffel-Munck, n 166 above, [62].

${ }^{176}$ Courtieu, n 169 above, [26]-[47].

177 Stoffel-Munck, n 166 above, [668]ff, [731] ff; Cadiet and le Tourneau, n 166 above, [81]; Fabre-Magnan, n 166 above, $80-82$ for whom 'the doctrine of abuse of rights is better suited to deal with [the misuse of] unilateral contractual discretions' than good faith.

${ }^{178}$ Stoffel-Munck, n 166 above, [731].

179 D. Mazeaud, La notion de clause pénale (LGDJ Paris 1992) [47]-[48] ; J. Raynard, 'Le domaine des prérogatives contractuelles: variété et développement' RDC 2011.695 [24 ;] F. Chabas, 'La réforme de la clause pénale (L No 75-597 du 9 juillet 1975)' D 1976 Chron.229; Y.-M. Laithier 'Clause pénale et dommages et intérêts incitatifs' in C. Jamin, (ed), Droit et économie des contrats (Paris : LGDJ, 2008) 141

${ }^{180}$ Art 1231-5 of the Civil Code.

181 ibid.

${ }^{182}$ Art 7.4.13 (see the Official Comments on this article: 'In order to prevent the possibility of abuse to which such clauses may give rise...'). 
European Contract Law ${ }^{183}$ and the Draft Common Frame of Reference, ${ }^{184}$ which were, along with French law, all cited in Makdessi. ${ }^{185}$ The premise of each of these rules is that 'to allow the parties complete freedom to fix the sum payable for non-performance may lead to abuse' ${ }^{186}$ and they serve 'to control only those stipulations which are abusive in their effect'. ${ }^{187}$

\section{CONCLUDING OBSERVATIONS: SOME POSSIBLE CHALLENGES FOR 'ABUSE OF RIGHTS'}

This article has sought to identify and explain the role of abuse in two specific areas that have been the subject of recent developments: contractual discretionary powers and damages clauses. It has argued that the limits imposed by the courts in these areas reflect a concern to prevent rights and freedoms being abused, and the parallels between them are suggestive of an underlying principle against the abuse of rights. To recognise this, at least in these contexts, is to enhance our understanding of the cases and how and where the line for impermissible conduct is drawn.

These arguments raise a number of further questions. Foremost is whether a principle against the abuse of rights might be covertly operating in English contract law in other contexts and, if so, with what scope and content and whether it is capable of being defined with precision. It might also be asked whether this could lead to reconsideration of the historical rejection of abuse of rights in English law. It is outside of the ambit of this article to seek to answer these broader questions but some concluding remarks will nonetheless be offered.

The question of whether or not there might be other manifestations of a broader principle against the abuse of rights in English contract law has not thus far been considered in any detail in the academic literature. ${ }^{188}$ There have been occasional hints but none have been developed. Vogenauer, for instance, has said that the traditionally hostility to the notion of abuse of rights 'does not exclude the possibility that English law frequently intervenes to censure or control actions by persons relying on their strict legal rights to the unfair disadvantage of others ${ }^{\prime 189}$ to combat opportunistic self-interest. In a contractual context, he has cited 'the equity of redemption in relation to mortgages and the law against clogs on the equity of redemption and the relief against forfeiture of leases' as examples. ${ }^{190}$ Similarly, Collins (writing prior to Braganza) identified the doctrines applied by the courts when reviewing the exercise of powers of committees of unincorporated associations, which should not be exercised arbitrarily, capriciously or irrationally, as examples of 'rules to protect members against the potential misuse of the powers of associations ... [which could] provide an interesting parallel and hint how a good faith or abuse of rights standard might be developed in English law for bilateral commercial contracts containing discretionary powers'. ${ }^{191}$

It is possible to think of other potential areas where the principle might be said to operate and which would merit further consideration. ${ }^{192}$ One is the right to affirm and claim the contract price following a repudiatory breach. ${ }^{193}$ This right is generally denied only in rare cases where the injured

\footnotetext{
${ }^{183}$ Art 9:505 (see the Comments and notes on this article: 'to allow the parties complete freedom to fix the sum payable for non-performance may lead to abuse...').

${ }^{184}$ Article III-3:710 (see the Comments on this article: 'to allow the parties complete freedom to fix the sum payable for non-performance may lead to abuse...').

185 Makdessi at [37] (Lord Neuberger and Lord Sumption); [165] (Lord Mance); [263] (Lord Hodge).

186 ibid.

187 ibid.

${ }^{188}$ Gutteridge, n 11 above; Catala and Weir, n 12 above; S. Vogenauer, 'Conclusion' in R. De La Feria and S. Vogenauer (eds), The Prohibition of Abuse of Law: An Emerging Principle of EU Law? (Oxford: Hart, 2011).

${ }^{189}$ Vogenauer, n 188 above, 556-557.

190 ibid.

${ }^{191}$ Collins, $\mathrm{n} 50$ above, 222-223.

192 The focus of this paper being on contractual discretions and penalties, it is beyond its scope (and spatial constraints) to explore in greater detail the possible link between abuse or rights and these areas, and instead they are identified as fertile ground for further analysis.

${ }^{193}$ White and Carter (Councils) Ltd v McGregor [1962] AC 413 (HL Sc).
} 
party has no 'legitimate interest' in keeping the contract alive and insistence on performing is 'wholly unreasonable', a 'commercial absurdity' or 'perverse'. ${ }^{194}$ It is a jurisdiction that catches only the most extreme and egregious cases and, as with contractual discretionary powers and penalty clauses, it might be argued operates only where the right is abused. Another potential area is promissory estoppel, ${ }^{195}$ which prevents a party from enforcing a contractual right where they have promised the other party that they will not do so. Relief is only available where the promise was clear and unequivocal, the other party detrimentally relied on it, and it would be inequitable for the right-holder to go back on their promise by enforcing the right. The right-holder is prevented from reneging on the promise in circumstances where, it could be argued, they seek to assert the right abusively.

If there was found to be significant implicit support for a broader principle against the abuse of rights, it might be asked whether it could be elevated into a free-standing and overarching doctrine. English law has traditionally been resistant to expansive and abstract doctrines and attempts to generalise from discrete rules have failed in the past. One such attempt by Lord Denning in Lloyds Bank Ltd $v$ Bundy ${ }^{196}$ to recognise a general doctrine of 'inequality of bargaining power' was firmly rejected by the House of Lords in National Westminster Bank Ltd $\vee$ Morgan. ${ }^{197}$ The more recent attempt by Leggatt J (as he then was) to promote the recognition of an implied duty of good faith in performance proved to be controversial and met with mixed reactions in later cases. ${ }^{198}$ English law tends to develop incrementally through 'piecemeal solutions in response to demonstrated problems of unfairness, ${ }^{199}$ not in broad sweeps with a heightened risk of linguistic indeterminacy and abstraction and definitional difficulties, ${ }^{200}$ and the attendant risk of greater uncertainty. As an opentextured and multi-faced concept, 'abuse' might be vulnerable to similar criticisms. ${ }^{201}$

Relatedly, it is also possible that 'abuse' could turn out to have different meanings and characteristics depending on the context. This is illustrated by abuse of rights in civil law jurisdictions, where there is no discernible alignment as to its meaning. ${ }^{202}$ The divergences relate not only to the definition of abuse but also its scope, shape and consequences. ${ }^{203}$ What qualifies as abusive and the test for abuse varies from country to country. Some civilian systems, for instance, confine the doctrine to cases where the right-holder intends to cause harm to others. ${ }^{204}$ It is more extensive and sophisticated in some others, where an intention to harm is simply one amongst several forms of abuse. It can also include exercising a right without any legitimate interest or inconsistently with its nature and purpose, regardless of any intention to harm. ${ }^{205}$ This uncertainty is said to be compounded by the ambit of the doctrine being unclear and contentious within certain civilian jurisdictions. ${ }^{206}$ Such uncertainties might not appeal to English lawyers, although it is important to note that it is not always

\footnotetext{
${ }^{194}$ Isabella Shipowner SA v Shagang Shipping Co Ltd (The 'Aquafaith') [2012] 1 CLC 899, [44] (Cooke J).

195 Hughes v Metropolitan Railways Co (1877) 2 App Cas 439; Central London Property Trust Ltd v High Trees House Ltd [1947] KB 130.

196 [1975] QB 326 (CA) (see in particular Lord Denning at 339).

197 [1985] AC 686 (HL) Lord Scarman at 707-708.

${ }_{198}$ Mid Essex Hospital Services NHS Trust v Compass Group UK and Ireland [2013] EWCA Civ 200 at [105] (per Jackson LJ): 'there is no general doctrine of 'good faith' in English law'.

199 Interfoto Picture Library Ltd v Stiletto Visual Programmes Ltd [1989] QB 433 (CA) 439 (per Bingham LJ).

${ }^{200}$ Vogenauer, n 188 above, 568-569.

${ }^{201}$ Gutteridge $n 11$ above, 43-44, for instance, has described abuse of rights as 'vague and indefinite in character' and as having salient features that are 'vacillation and nebulosity'.

${ }^{202}$ As the pan-European study by Voyame, Cottier and Rocha, $\mathrm{n} 12$ above at 23 states, there are 'almost as many conceptions of the abuse of rights as there are member states of the Council of Europe'.

${ }^{203}$ Voyame, Cottier and Rocha, n 12 above 23.

204 International Encyclopaedia of Comparative Law (n 11) [255] citing the Scandinavian countries and Italy.

205 International Encyclopaedia of Comparative Law, n 11 above; Crabb, n 12 above; Reid, n 12 above, 136; see for French law, Cadiet and le Tourneau, n 166 above; Yiannopoulos, n 12 above, at 1180-1185 describing the jurisprudence constante in Louisiana; New Civil Code of Quebec, art 7.

${ }^{206}$ Gutteridge, n 11 above, 42-43.
} 
seen as problematic in civilian jurisdictions. A degree of malleability is thought to engender flexibility, enabling the court to achieve justice case-by-case. ${ }^{207}$

It is however important to recognise the limitations on what can be learned from the lack of alignment across civilian systems. That there is no universal and authoritative definition of abuse does not mean that such a definition is necessarily out of reach or any further out of reach than in other areas where a relatively high-level test or principle falls to be applied by the courts. The content and scope of any doctrine of abuse would be found in and informed by the specific principles and rules that the doctrine enshrines. As in other contexts, any uncertainty should further reduce as the doctrine is refined in the cases in those areas where it is found to be relevant. ${ }^{208}$

${ }^{207}$ Gutteridge, n 11 above, 43: 'the concept of abuse is ... left purposely vague and the judges are trusted to apply it'. In the context of French law, Fabre-Magnan, above, n 166 notes that the Cour de cassation 'keeps an extremely close watch on the doctrine to make sure that its criteria remain uncertain'.

208 See the arguments of Vogenauer, n 188 above in the context of whether the prohibition of abuse of law is an emerging principle of EU law and Gordley, n 11 above, 43. 